\title{
The Relationship between Reading Dyslexia and Academic Performance of Upper Primary Pupils in Public Schools in Changamwe Sub-County, Kenya
}

\author{
Veronicah Kaluyu $^{1}, \&$ Pamela Ooko ${ }^{2}$ \\ ${ }^{1}$ Africa Nazarene University (ANU). Box 53067, 00200, Nairobi, Kenya. Tel.: +254 (20) 2527170 \\ ${ }^{2}$ Africa Nazarene University (ANU). Box 53067, 00200, Nairobi, Kenya. Tel.: +254 (20) 2527170 \\ Correspondence: Dr. Veronicah Kaluyu, Africa Nazarene University (ANU). Box 53067, 00200, Nairobi, Kenya.
}

Received: February 22, 2016

Accepted: March 21, 2016

Available online: March 23, 2016

doi:10.11114/ijsss.v4i5.1489

URL: http://dx.doi.org/10.11114/ijsss.v4i5.1489

\begin{abstract}
The present study examined the relationship between reading dyslexia condition and academic performance in upper primary learners in Kenyan public schools in Changamwe Sub County, Mombasa County. The study used a purposive sampling method and the sample consisted of 160 learners and 43 teachers from six different schools. Correlational Ex-Post Facto research design was used based on three major examinations done in Term 1 and Term 2. Questionnaires were used to collect data from teachers. A test re-test method was used to test reliability of the instruments using both Cronbach's Alpha and Pearson's correlation coefficient (r) at 5 percent critical level. Descriptive statistics of mean, frequencies, percentages, standard deviations were used to analyze data while Pearson product moment correlations were used to test hypotheses. The data was analyzed using Stata11 software. The study found that there was a statistically significant correlation $(\mathrm{p}<0.05)$ between academic performance and reading $\left(\mathrm{r}=0.4876^{*}, \mathrm{p}=0.000\right)$ in upper primary pupils in public schools. The study recommends formulation of education policies catering on the screening, teaching, learning, assessment and examination of dyslexic pupils in public primary schools in Kenya. The study also recommends restructuring the teacher training curriculum to equip teachers with skills to handle reading dyslexics.
\end{abstract}

Keywords: Reading Dyslexia, Academic performance

\section{Introduction}

\subsection{Reading Dyslexia}

The concept of reading dyslexia which is defined as the inability of the learners to read well, relate sounds to their corresponding letters was first put forward in1881(Berkhan,1917). Dyslexia is coined from two Greek words 'Dys' meaning trouble and 'lexia' meaning words (Berninger \& Wolf, 2009). However these studies did not relate reading dyslexia to academic performance. Reading dyslexia is a language deficit condition believed to be affecting 80 percent of learners with learning difficulties despite effective instruction and high intelligence of some learners. It is the most common learning difficulty which affects the decoding, word recognition, rapid automatic naming, and reading-comprehension skills. Learning to read involves proficiency in relating symbols of the writing system to the sound that they represent in a language (Hulme \& Snowling, 2012). According to the International Dyslexia Association (2012), 10-20 percent of the world's population is estimated to have Dyslexia while 13-14 percent of the school-going children in America exhibit signs of dyslexia (IDA, 2009).

Although dyslexia is acknowledged as a learning condition in many parts of the world, the actual numbers affected by the condition may not be known in Africa, due to lack of awareness and a clear definition (Iwan, 2013). In Egypt it is assumed that dyslexia affects 1 percent of the population. In South Africa it is estimated that 10 percent of the people are suspected to have dyslexia (Iwan, 2013). In Kenya, it is not clear what percentage is affected though the prevalence is estimated to be about 10 percent (Symthe, Everatt, Ocampo, \& Gyarmathy, 2004). Earlier studies on reading dyslexia and academic performance are rare in Kenya.

Available studies listed factors affecting academic performance as quality of curriculum (World Bank Policy Paper on Education, 1990), School leadership (Eshiwani, 1983), Sufficient knowledge Kirigia (1991), and socioeconomic 
factors (Katana \& Jagero, 2010). From the literature reviewed, it was apparent that learners with reading problems meet a lot of problems in the primary schools. Some of them are stigmatized and humiliated by the teachers. According to Connely, et.al (2006) students with dyslexia have poor spelling, punctuation and organization of ideas apart from poor grammar and sentence construction. These problems are reflected in their academic work where they manifest in terms of reading words wrongly or poor comprehension (Hulme \& Snowling, 2011). This particularly drew the researcher to find if there could be a relationship between reading dyslexia and academic performance.

\subsubsection{Theoretical implication of the study}

This study was guided by the Phonological theory (Ramus, Rosen, Dakin, Day, Castellote, White \& Frith, 2003). The theory attempts to explain how sound in a language is developed and used to encrypt meaning. The phonological theory talks about a shortage in a part of language system which deals with grapheme (letter) and phoneme (sound) processing. If a learner has a problem in relating the sound and symbol in a word, the learner may not read the word correctly. This study affirms the assertions of this theory.

\subsection{Importance of the problem}

According to Sessional Paper No 1 (Republic of Kenya, 2005), there is no accurate data on the number of learners with learning difficulties in primary schools in Kenya. With no reliable data on special needs children in the country, dyslexia as a learning difficulty is largely generalized and thus given minimal attention. Public primary schools in Changamwe Sub-County had recorded the poorest performances in KCPE between the years 2012-2014. The poor performance in KCPE in the county elicited the need for this study, which attempted to establish if there was a relationship between reading dyslexia and academic performance. Study findings are likely to shade more light on the need to give specialized attention on children with reading dyslexia challenges.

\subsection{Relevant scholarship}

In a study done in Germany, by Schulte-Korne et al, (2006) to investigate short term memory, it was found that children with this condition tended to be slower at spelling, recognizing words, and naming letters rapidly. This then interfered with their reading, comprehension and vocabulary. Another study done in America by Shanahan et al. (2006) on the mental processing speed of dyslexic children in primary schools using 'verbal output' where they were naming items and manipulating a keyboard at the same time, found dyslexics to be slow at pronouncing words and motor coordination. Vaessen, Gerretsen, and Blomert (2009) also found them to be slow at 'phoneme deletion accuracy, phoneme deletion speed, rapid automatic naming of letters and digits, object naming speed, visual coding, and digit span'. This slow speed interfered with phoneme-grapheme association (word-sound segmentation) consequently delaying reading. . Earlier studies conducted in Kenya highlights that learners with problems in reading English have problems in school performance in general (Chege 1999, Kirigia $1991 \&$ Njoroge 2000). A study conducted by Wanjiku (2015) to investigate the effects of reading difficulties on academic performance of form three students in public schools in Kiambu found that learners with problems in reading English had problems in school performance. This agrees with the finding of this study which found that there was a strong positive relationship between reading dyslexia and a learner's academic performance. Rasugu(2010) carried out a research to find out the nature and prevalence of learning disabilities among standard three pupils of Starehe division. The study found that there were more males with learning disabilities than the female cases.

\subsubsection{Objectives of the study}

The main objective formulated for the purpose of the study was to find out the relationship between reading dyslexia and academic performance in upper primary pupils in public primary schools in Changamwe Sub County.

\subsubsection{Hypothesis}

In order to carry out the investigation, the following hypothesis was formulated:

There is no statistically significant correlation $(\mathrm{p}<0.05)$ between reading dyslexia and academic performance in upper primary pupils in public schools in Changamwe Sub County, Kenya.

The hypothesis tested was:

Ho: There is no statistically significant correlation $(\mathrm{p}<0.05)$ between reading dyslexia and academic performance in upper primary pupils in public schools in Changamwe Sub County, Kenya.

\section{Method}

The researcher used the correlation Ex-post facto research method to describe the nature of the relationship between these variables by identifying the magnitude of the relationship using a statistical measure (r). This design uses data that is already collected for correlating the relationship between the variables (Kerlinger, 1986). Correlational Ex-Post Facto design used the dependent variable, overall academic performance, to examine associations with the independent 
variables; English Composition, English language and Mathematics. The researcher also examined pupils in reading comprehension independently. The dependent variable was the overall academic performance derived from three major examinations. Two of the examinations were done in first term (Mid Term and End Term) and one examination (Mid Term 2) was done in second term of 2015. A mean average was calculated for English, Mathematics, Science and Social Studies across the three examinations and the results totaled to give the pupils' overall academic performance. The averages were calculated to get an objective and reliable measure for academic performance.

\subsection{Population and Sampling of the study}

The population of the study comprised of upper primary learners from 20 public schools in Changamwe Sub County, Mombasa County. In the study, purposive sampling was used. A total of 160 learners constituted the sampling group. Consequently 43 language teachers helped in identifying learners who had dyslexic characteristics.

\subsection{Data collection Tools}

Two different scales were used in the study. In order to determine whether reading affected academic performance, questionnaires were used to collect data from teachers and the Bangor dyslexia test was used to identify reading dyslexic pupils. The statistical analysis of data was done using Stata11 Statistical Package. In addition correlational analysis was carried out to find the relationship between reading and academic performance.

\subsection{Reliability Analysis}

Reliability is when the research instrument gives consistent results (Kothari, 2004). It can be improved by standardizing the conditions under which a measurement takes place. The subjects of study were identified and screened by teachers before the Bangor Dyslexia Test was used to confirm dyslexic characteristics. The questionnaires were pilot-tested in one of the non-sampled schools. A Test- Retest method was used to test for reliability among 20 pupils consisting of 10 females and 10 males within a span of two weeks. Internal consistency techniques of Cronbach's Alpha were used. A coefficient of 0.6-0.7 is commonly agreed as acceptable although a reliability coefficient of 0.8 or higher is always preferred (Mugenda \& Mugenda, 2003). The Bangor test showed Cronbach's Alpha scale reliability coefficient of 0.8984 while the teacher questionnaire's coefficient was 0.6002. The Test-Retest Bangor test scores had a strong positive Pearson's correlation coefficient of 0.8155 . The Bangor dyslexia test and the teachers' questionnaires were then considered reliable for the study.

\subsection{Participant characteristics}

The participants were upper primary learners from classes 5-8 purposively selected from 6 of the 20 schools in the Sub-county. The learners with dyslexic characteristics in the English Language class were identified after disqualifying those who showed signs of inability to read as a result of other factors such as teacher quality, truancy, absenteeism and home factors.

\subsubsection{Sample size}

The researcher purposively selected a sample of 6 public primary schools with a population of 2639 pupils and 47 English Language teachers. The sample of 6 schools represented $33.3 \%$ of the 20 schools.

\subsubsection{Research Design}

A research design is a structure that shows how all the parts of a research project work together to address the research questions (Kombo \& Tromp, 2006). The research design used was Correlational Ex-post Facto design.

\section{Results}

The present study was carried out with a view to determine the relationship between reading dyslexia and academic performance of upper primary learners in public schools in Changamwe Sub County, Kenya. In the study data belonging to 160 learners (male 91 and 69 female) was evaluated. According to the results (Table 2), the correlation between reading and overall academic performance was $r(158)=0.4876^{*}, p<0.05$. Therefore there was a statistically significant correlation between reading and academic performance. From the coefficient of determination $\left(\mathrm{r}^{2}\right)$, reading explained 23.8 percent of the overall academic performance. Academic performance is also composed of English Composition, English Language and Mathematics. The English Composition combines both the ability to read, write and logically sequence ideas. When reading was correlated with writing, there was a statistically significant moderate positive correlation, $\mathrm{r}(158)=0.5559^{*}, p<0.05$ meaning that as the grades in reading increased the writing ability similarly increased. The correlation between reading and English Composition was equally statistically significant, moderate and positive, $\mathrm{r}(158)=0.3867^{*}, p<0.05$ meaning that as the reading ability increases the ability to write composition also increases. English Language is composed of comprehension component which tests the pupils' ability to understand what is being read. It also tests recall and making inferences. When reading was correlated with English Language, there was a statistically significant strong positive correlation, $\mathrm{r}(158)=0.6741^{*}, p<0.05$ meaning that as the 
reading ability increases the ability to read sentences correctly and comprehend them also increases. From the coefficient of determination $\left(\mathrm{r}^{2}\right)$, Reading therefore explained 45.4 percent of the English Language grades.

Table 1. Correlation between Reading and Academic Performance in various classes

\begin{tabular}{lrrrrrrr}
\hline & \multicolumn{1}{c}{ Class 5 } & \multicolumn{1}{c}{ Class 6 } & \multicolumn{1}{c}{ Class 7 } & Class 8 & All Classes & \multicolumn{1}{c}{ Male } & Female \\
\hline Overall & $0.5494^{*}$ & $0.3813^{*}$ & $0.3340^{*}$ & $0.5663^{*}$ & $0.4876^{*}$ & $0.5288^{*}$ & $0.4151^{*}$ \\
$\begin{array}{l}\text { Academic } \\
\text { Performance }\end{array}$ & & & & & & & \\
$\begin{array}{l}\text { Sig. Level } \\
\text { Observations }\end{array}$ & 0.0008 & 0.0127 & 0.0286 & 0.0001 & 0.0000 & 0.0004 & 0.0004 \\
& 34 & 42 & 43 & 41 & 160 & 91 & 69 \\
\hline
\end{tabular}

*. Correlation is significant at the 0.05 level

Table 1 shows that Reading had a statistically significant moderate positive correlation with academic performance in all the classes, beginning with class $5, \mathrm{r}(32)=0.5494, \mathrm{p}<0.05$. In class 6 , a similar statistically significant moderate positive correlation was registered, $r(40)=0.3813, p<0.05$. In Class 7 , the correlation between reading and academic performance was statistically significant moderate and positive as well, $\mathrm{r}(41)=0.3340, \mathrm{p}<0.05$. The correlation between reading and academic performance was statistically significant moderately positive and higher in Class $8, \mathrm{r}(39)$ $=0.5663, \mathrm{p}<0.05$.

Among the females a statistically significant moderate positive correlation was noted between Reading and Overall Performance $\mathrm{r}(67)=0.4151, \mathrm{p}<0.05$ while in males, a similar statistically significant moderate and positive correlation was noted between Reading and Overall Performance, $r(89)=0.5288, \mathrm{p}<0.05$.

Table 2. Correlation between All Variables

\begin{tabular}{|c|c|c|c|c|c|c|}
\hline & Reading & Writing & Composition & Language & Mathematics & $\begin{array}{l}\text { Overall } \\
\text { Academic } \\
\text { Performance }\end{array}$ \\
\hline $\begin{array}{l}\text { Reading } \\
\text { Sig. Level } \\
\text { Observations }\end{array}$ & 160 & & & & & \\
\hline $\begin{array}{l}\text { Writing } \\
\text { Sig. Level } \\
\text { Observations }\end{array}$ & $\begin{array}{l}0.5559 * \\
0.0000 \\
160\end{array}$ & $\begin{array}{l}1.0000 \\
0.0000\end{array}$ & & & & \\
\hline Composition & $0.3867 *$ & $0.6851 *$ & 1.0000 & & & \\
\hline $\begin{array}{l}\text { Sig. Level } \\
\text { Observations }\end{array}$ & $\begin{array}{r}0.0000 \\
160\end{array}$ & $\begin{array}{c}0.0000 \\
160\end{array}$ & 0.0000 & & & \\
\hline $\begin{array}{l}\text { Eng. } \\
\text { Language }\end{array}$ & $0.6741 *$ & $0.4733^{*}$ & $0.5757 *$ & 1.0000 & & \\
\hline Sig. Level & 0.0000 & 0.0000 & 0.0000 & 0.0000 & & \\
\hline Observations & 160 & 160 & 160 & 160 & & \\
\hline $\begin{array}{l}\text { Overall } \\
\text { Academic } \\
\text { Performance }\end{array}$ & $0.4876^{*}$ & $0.4912 *$ & $0.5790^{*}$ & $0.6979 *$ & $0.6631 *$ & 1.0000 \\
\hline Sig. Level & 0.0000 & 0.0000 & 0.0000 & 0.0000 & 0.0000 & \\
\hline Ubservations & 160 & 160 & 160 & 160 & 160 & 160 \\
\hline
\end{tabular}

*. Correlation is significant at the 0.05 level

In Table 2 there was a strong positive correlation between reading and writing, $\mathrm{r}(158)=0.5559, p<0.05$. There was however a statistically significant moderate positive correlation between reading and composition, $\mathrm{r}(158)=0.3867, p<$ 0.05. Correlation between Reading and Overall Performance was equally statistically significant moderate and positive at, $\mathrm{r}(158)=0.4876^{*}, \mathrm{p}<0.05$ showing a relationship between the two. 


\subsection{Testing Hypothesis}

The researcher used Pearson's product moment correlation coefficient to test the hypothesis. The data from all the 160 pupils who were screened and suspected to exhibit dyslexic characteristics were used. The Regression Analysis was carried out to check how reading, writing, and mathematics predicted the overall performance.

Table 3. Contribution of Reading, Writing and Mathematics dyslexia to academic performance

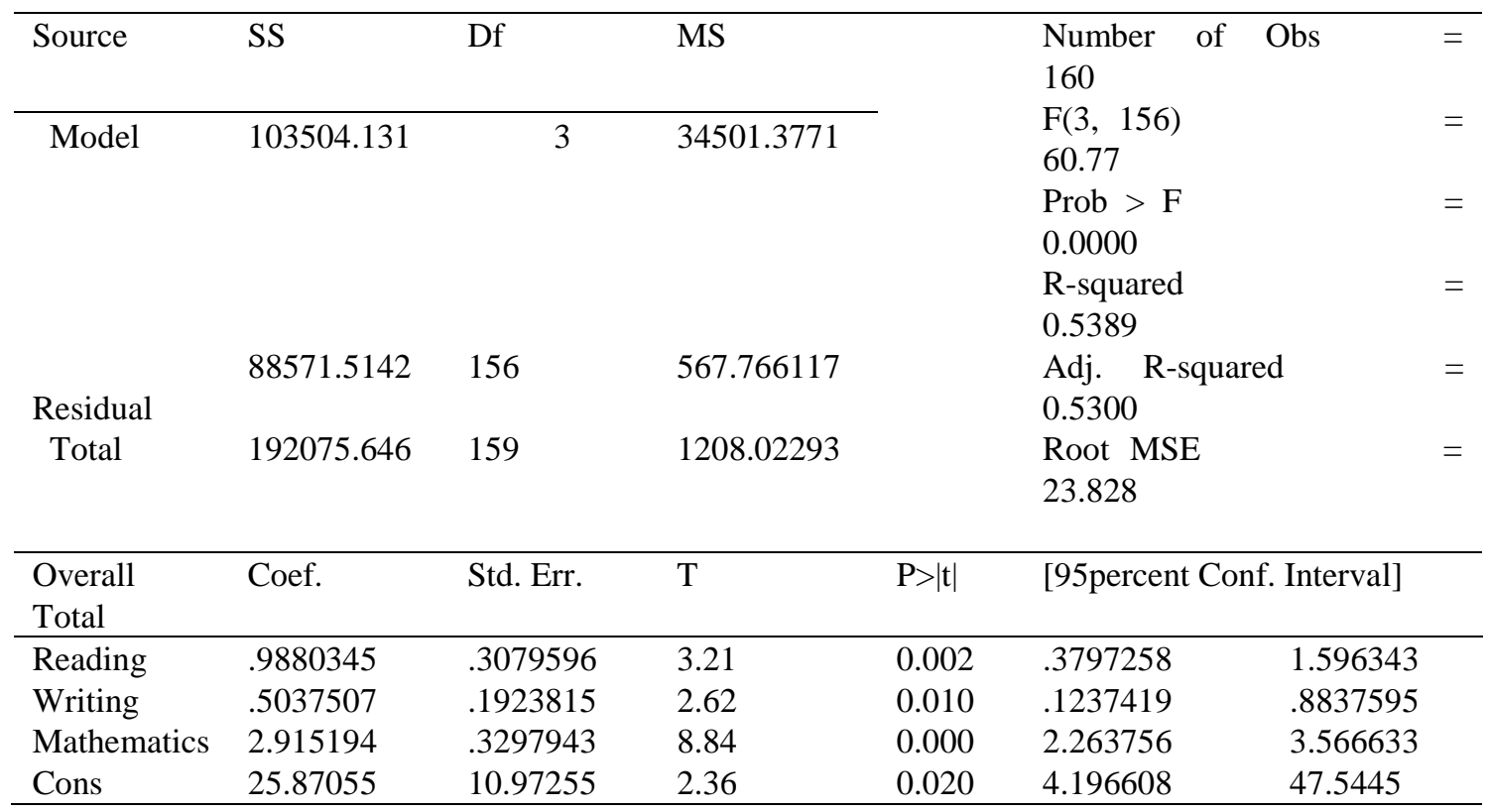

A multiple regression analysis was run to predict academic performance from Reading, Writing and Mathematics in Table 3. These variables statistically significantly predicted academic performance, $F(3,156)=60.77, p<0.05, R^{2}=0.5389$. All three variables added statistically significantly to the prediction, $p<0.05$. From the $\mathrm{F}$ statistics the calculated value was 60.77 while the table value was 215.71 . Since 60.77 was less than 215.71 it was a good fit. In reference to the coefficient of determination $\left(\mathrm{r}^{2}\right)$, therefore the Reading, Writing and Mathematics grades explained over 53 percent of the overall academic performance.

The Null hypothesis is therefore rejected and the alternative accepted. There is statistically significant correlation $(\mathrm{p}<$ 0.05 ) between reading dyslexia and academic performance in upper primary learners in public schools in Changamwe Sub County, Kenya.

\subsection{Bangor Test Results got from Identifying Students with Dyslexic characteristics}

The Bangor Test (Miles, 1997) was used to measure cognitive abilities like short-term and working memories. It was also used to examine spatial awareness across sub-tests of laterality (Left-right body parts), repeating polysyllabic words, subtraction, and multiplication tables, month's forwards and backwards among others.

The scoring was based on each sub-test's result with (+) indicating a positive dyslexic result, (-) showing negative while (0) meant an ambiguous result. A summation of the positives and negatives was then done where the zeroes were treated as half positives. The more positive the summation was, the higher the risk of Dyslexia.

Table 4. Bangor Dyslexia Test Results

\begin{tabular}{lcc}
\hline Indicators for Dyslexia & $\begin{array}{c}\text { No. of Positive (+) indicators in } \\
\text { the pupils out of } 160\end{array}$ & Percentage (percent) \\
\hline Laterality (Left-right body) )parts) & 115 & 71.88 \\
Repeating polysyllabic words & 153 & 95.63 \\
Months forwards & 140 & 87.50 \\
Months backwards & 153 & 95.63 \\
Digits forwards & 147 & 91.88 \\
Digits reversed & 153 & 87.63 \\
b-d confusion & 140 & 84.30 \\
Familial incidence & 135 & \\
\hline
\end{tabular}

From the table the most prevalent positive results from the 160 pupils after taking the Bangor Dyslexia Test were based on reading polysyllabic words (95.63 percent). From phonological theory, phonological awareness involves relating the grapheme (letter) and phoneme (sound). Pupils with dyslexic characteristics erase phonemes at the beginning and end of 
words. The researcher noted that the pupils hesitated during the reading process as well. Reciting months and digits both forwards and in reverse proved a challenge to pupils, too. According to phonological Theory, this was indicative of weak reading skills and problems with short term memory usually associated with dyslexia. Other prominent positive indicators of dyslexia included b-d confusion and subtraction (mental arithmetic). The researcher used the Bangor Test and Hardin, Simmons University (2014) tool for identifying dyslexic characteristics in children. The analysis was thus based on the screening test results. The researcher also noticed cases of brothers and sisters with dyslexia (84.38) percent. This is in line with the findings of the International Dyslexia Association (2012) which stated that dyslexia ran in families and having a parent or sibling with dyslexia increased the probability of one having dyslexia.

\subsection{Results from Reading comprehension Test}

Table 5. Results from the Reading Comprehension Test

\begin{tabular}{lcccc}
\hline \multicolumn{1}{c}{ Question } & $\begin{array}{c}\text { Answered } \\
\text { Correctly }\end{array}$ & Percentage & $\begin{array}{c}\text { Answered } \\
\text { Wrongly }\end{array}$ & Percentage \\
\hline 1. What type of day was it? & 70 & 43.75 & 90 & 56.25 \\
2. What had the sun done? & 80 & 50.00 & 80 & 50.00 \\
3. Which activities took place on that & 65 & 40.62 & 95 & 59.33 \\
& & & & \\
4. day? & 40 & 25.00 & 120 & 75.00 \\
\hline
\end{tabular}

The researcher examined the pupils in a Reading Comprehension Test. Comprehension refers to understanding what has been read. It is an active, thinking process that depends not only on comprehension skills but also on the student's experiences and prior knowledge. Comprehension involves understanding the vocabulary, seeing the relationships among words, concepts and organizing ideas. From the findings in Table 5, the most challenging question to the learners was Question 4 which involved comprehension and recall. A total of 120 (75 percent) of the pupils tested could not get it right. The least challenging question to the pupils was Question 2 where half of the learners correctly got the answer. This question tested simple recall. Majority of the pupils had issues with comprehending the words they had just read or seen which are key pointers to dyslexic characteristics according to Davis and Braun (1994, p. 20).

All these attributes constitute phonological awareness. The researcher also examined pupils in Reading Comprehension. The majority of the pupils (75 percent) could not comprehend and recall relatively challenging parts of an English passage. Some of them (59.33 percent) had problems remembering and sequencing the activities that took place in the passage. Reading comprehension is affected by word reading efficiency and vocabulary knowledge (Wong, 2004).

\subsection{Results on the Effect of Reading dyslexia on Academic Performance}

Table 6. Effects of Dyslexia

\begin{tabular}{llllll}
\hline Variable & Obs & Mean & Std. Dev. & Min & Max \\
\hline Reading dyslexia affects academic performance & 43 & 4.906977 & .2939026 & 4 & 5 \\
Dyslexia affects overall academic performance & 43 & 4.581395 & .4991687 & 4 & 5 \\
Dyslexia affects word reading & 43 & 4.55814 & .5024855 & 4 & 5 \\
Dyslexia affects ordering of alphabetical letters & 43 & 4.55814 & .5024855 & 4 & 5 \\
Dyslexia affects writing ability & 43 & 4.627907 & .4890835 & 4 & 5 \\
\hline
\end{tabular}

In Table 6, the researcher sought to find out the effects of reading dyslexia on academic performance. It was found that reading dyslexia affects reading, ordering of alphabetical letters, writing ability and consequently academic performance. From the data, teachers could not identify dyslexia ( 88.37 percent), they had no time to support pupils with dyslexia (76.74 percent) and lacked resources for identifying and assessing dyslexic characteristics. Besides the large class sizes could not allow them to help pupils with individual needs. From the data, 69.77 percent of the teachers had classes of over 70 pupils each.

\subsection{Results on Teacher's views on Dyslexia}

Table 7. Teachers' views on Dyslexia 


\begin{tabular}{lccccc}
\hline Variable & Frequency & Mean & Std. Dev. & Min & Max \\
\hline Ability to identify dyslexia & 43 & 1.883721 & .9311872 & 1 & 5 \\
Know the causes of dyslexia & 43 & 1.674419 & .6444241 & 1 & 4 \\
Screening resources & 43 & 1.395349 & .4947118 & 1 & 2 \\
Time for support & 43 & 1.27907 & .4538503 & 1 & 2 \\
Teachers training & 43 & 1.348837 & .5293177 & 1 & 3 \\
Sharing of information & 43 & 1.581395 & .9317817 & 1 & 4 \\
Parents acknowledgement & 43 & 1.186047 & .5002768 & 1 & 3 \\
Parents-Teacher cooperation & 43 & 1.511628 & 1.222256 & 1 & 5 \\
\end{tabular}

The study sought to find out if teachers in the study were able to identify cases of reading dyslexia or whether schools allocated adequate resources to identify and manage dyslexia (Table 7). The majority of the teachers heard about dyslexia for the first time hence had no ability to identify dyslexia (Mean $=1.88$, std dev. $=0.93$ ). They also did not know the causes of dyslexia (mean $=1.67$, std dev. $=0.64$ ) although the answers had some variation. Giving varied ratings, the teachers were unanimous that schools did not commit any resources (mean $=1.39$, std dev $=0.49$ ) or time to support (mean $=1.28$, std dev. $=0.45)$ students with learning needs like Dyslexia. Besides, the teachers were not trained on managing dyslexia (mean $=1.34$, std dev. $=0.53$ ) and they were equally not sharing information on pupils with learning needs among themselves (mean $=1.6$, std dev. $=0.93$ ).

\subsection{Effect of Teacher's Class sizes on reading Dyslexia}

Table 8. Teachers' Class sizes

\begin{tabular}{lcc}
\hline Class Size & Frequency & Percent \\
\hline $0-40$ pupils & 1 & 2.33 \\
$41-50$ pupils & 4 & 9.30 \\
$51-60$ pupils & 8 & 18.60 \\
60-70 pupils & 0 & 0.00 \\
Over 70 pupils & 30 & 69.77 \\
\hline & 43 & 100.00
\end{tabular}

The study also sought to determine if class sizes affected the ability of the teachers to identify reading dyslexia. This was in line with the findings of Martin (2008), who stated that a crowded classroom was a major impediment to identifying children with learning difficulties such as dyslexia.

From the table, the majority of teachers (69.77 percent) reported large class sizes of over 70 pupils. In cases where they were fewer, most classes had an enrolment above 50 pupils per class. The large class sizes could be linked to the implementation of Free Primary Education policy in 2003 after the then NARC government came into power (Otach, 2008).The study found that learners in large classes were more prone to having a learning difficulty than those in smaller classes.

\section{Discussion}

The objective for the study was to establish the relationship between Reading Dyslexia and academic performance of upper primary pupils in public schools in Changamwe Sub County. Reading had a statistically significant moderate positive correlation with academic performance in all the classes, beginning with class $5, \mathrm{r}(32)=0.5494, p<0.05$. In class 6 , a similar statistically significant moderate positive correlation was registered, $\mathrm{r}(40)=0.3813, p<0.05$. In Class 7 , the correlation between reading and academic performance was statistically significant, moderate and positive as well, $\mathrm{r}(41)=0.3340, p<0.05$. The correlation in standard 8 was statistically significant and moderately positive, $\mathrm{r}(39)=$ $0.5663, p<0.05$. The correlations were also run according to gender. In females pupils, reading when correlated with academic performance remained statistically significant, moderate and positive, $\mathrm{r}(67)=0.4151, p<0.05$. The males also returned a statistically significant moderate positive correlation with academic performance, $\mathrm{r}(89)=0.5288, p<$ 0.05. Phonological theory attempts to explain how sound in a language is developed and used to encrypt meaning. Reading Dyslexia impairs how symbol and sound is associated. The positive correlation between reading and academic performance means dyslexia by extension impacts negatively on pupils' reading and consequently on academic 
performance). These findings are consistent with those of Wanjiku (2015) which investigated the effects of reading difficulties on academic performance of students in public schools in Kiambu and found that learners with problems in reading English had problems in school performance. There were more males with dyslexic characteristics than females. This is in line with the findings of Rasugu (2010) carried out to find out the nature and prevalence of learning disabilities among standard three pupils of Starehe division. The study found that there were more males with learning disabilities than the female cases.

\subsection{Limitations of the study}

The methodology used solicited ideas from people whose social construction of reality may be influenced by other factors beyond control.

\subsection{Recommendations of the study}

From the findings of the research it was evident that most teachers in the primary schools found difficulty in distinguishing reading dyslexia from other learning disabilities. There should be regular in-servicing of all teachers to equip them with skills of identifying reading dyslexia and new ways of supporting learners with learning difficulties. It was evident that identifying a child with reading dyslexia is difficult for both the parents and teachers. Teachers in the public primary schools should make use of differentiation practice where they attend to the learners based on their academic capabilities. The government should consider giving pupils with reading dyslexia special considerations when it comes to administering, marking and grading of the tests and examinations. Teachers should also design ways to motivate the learners. This could be done through praise, or use of mechanisms like star-awards for reading correctly. They could also allocate time for individual support of learners with dyslexic characteristics. Every day the teachers can organize special times where the pupil is given a few minutes to read story books before the lessons begin. Teachers should also make use of learning aids such as flash cards. Similarly in the upper primary where reading is mostly silent, teachers need to use innovative teaching methodologies and some lessons need to be structured for reading aloud to allow those with learning difficulties to practice their reading skills. The teachers can also use learning materials with big letters and spaces between them.

\section{Conclusion}

The study found that there was a statistically significant relationship between reading dyslexia and academic performance. Dyslexia greatly impairs the pupil's ability to read, comprehend and organize ideas. This greatly affected their academic performance since all subjects in the curriculum involve reading and comprehension. The effect of dyslexia equally compromised the pupils' ability to write legibly. The unresolved problem is that teachers in the primary schools are not able to differentiate reading disabilities caused by other factors from those that result from dyslexia.

\section{Acknowledgements}

The authors acknowledge Africa Nazarene University for provision of enabling research environment that made it possible to accomplish this study.

\section{References}

Adediwura, A. A., \& Tayo, T. (2007). Perceptions of teacher knowledge, attitude and teaching skills as predictor of Academic Performance in Nigerian Secondary Schools. Educational Research and Review, 2(7), 165-171.

Becher, R. M. (1985). Parent involvement and reading achievement: a review of research and implications for practice. Childhood Education, 62(1), 42-50.

Berkhan, O. (1917). UberdieWort blind heit, einstaminelnimsprechen und schreiben, einfehlim Lesn Neurobiologisches Centralblatt, 36, 914-927.

Berninger, V. W., Nielsen, K. H., Abbott, R. D., Wijsman, E., \& Raskind, W. H. (2008). Writing problems in developmental dyslexia: Under-recognized and under-treated. Journal of School Psychology, 46, 1-21.

Berninger, V., \& Wolf, B. (2009). Teaching students with dyslexia and dysgraphia: Lessons from teaching and science. Baltimore: Brookes.

Callens, M., Tops, W., \& Brysbaert, M. (2011). Cognitive profile of higher education students with an indication of dyslexia. Manuscript submitted for publication

Chege, E. W. (1999). Reading comprehension and its relationship with academic performance among standard eight pupils in rural Machakos. M.Ed. Thesis at Kenyatta University.

Connelly, V., Campbell, S., MacLean, M., \& Barnes, J. (2006). Contribution of lower order skills to the written composition of college students with and without dyslexia. Developmental Neuropsychology, 29, $175-196$. http://dx.doi.org/10.1207/s15326942dn2901_9 Retrieved on 29 ${ }^{\text {th }}$ August, 2014. 
Davis, R. D., \& Braun, E. M. (1994). The gift of dyslexia. Perigee: New York.

Diehl, J. D., Frost, S. J., Mencl, W. E., \& Pugh, K. R. (2011). Neuroimaging and the phonological deficit hypothesis. In S. Brady, D. Braze, \& C. Fowler (Eds.), In Explaining individual difference in reading theory and evidence. New York, NY: Psychology Press.

Eshiwani, G. (1983). Factors influencing performance among primary and secondary school pupils in Western Province in Kenya. A policy study.

Hardin Simmons University. (2014). Characteristics of dyslexia. Retrieved on 19th September, 2014 from https//;www.hsutx.edu

Hulme, C., \& Snowling, M. J. (2011). Children's Reading Comprehension Difficulties: Nature, Causes, and Treatments. Current, 20(3), 139.

Hulme, C., \& Snowling M. (2012). The nature and classification of reading disorders, a commentary on proposals for DSM. Journal of child psychology and psychiatry. http://dx.doi.org/10.1111/ J.1467-7687.2011.01129.x Retrieved on August, 6 th 2014.

International Dyslexia Association (2009). Just the Facts. Recommended reading for Parents, 1-2. Retrieved on October 1, 2014, from IDA website, www.interdys.org.

International Dyslexia Association (2012). Dyslexia in the classroom. What Every Teacher should know. Baltimore M.D 21202. Retrieved from Info@interdys.org www.interdys.org on August, 12 th 2015.

Iwan, P. (2013). Addressing the challenges of dyslexia. The Mail guardian. Retrieved from mg.co.za/article/ 2013-09-20-00- addressing the challenges of dyslexia.

Jagero, N., Agak, J., \& Ayodo, T. (2010). An Evaluation of Home Environmental

Factors Affecting Performance of Boarding Secondary School Students in Kenya, Analytical Reports in International Education, 3(1), 47-62.

Jordan, A., \& Stanovich, P. (2001). Patterns of teacher-student interaction in inclusive elementary classrooms and correlates with student self-concept. International Journal of Disability, Development and Education, 48, 33-52.

Kerlinger, F. N. (1986). Foundations of Behavioral Research. Fort Worth: Holt, Rinehart \& Winston.

Kiai, A. (2012). Koi and the Dirty Road. Sasa Sema Publication, Nairobi. Kenya.

Kirigia, K. E. (1991). Assessment of English reading comprehension of pupils completing primary education. A cases study of Meru municipality zone. A master's research thesis: Kenyatta University.

Kombo, K. D., \& Tromp, D. (2006). Proposal and Thesis writing: Pauline Publications Africa 7th Reprint.

Lyon, G. R., Shaywitz, S. E., \& Shaywitz, B. A. (2003). Defining dyslexia, comorbidity, teachers' knowledge of Language and Reading: A definition of dyslexia. Annals of Dyslexia, 53, 1-14.

Martin, D. (2008). A new paradigm to inform inter-professional learning for integrating speech and language provision into secondary schools: a socio-cultural activity theory approach. Child Language Teaching and Therapy, 24, 173192.

Miles, T. R. (1997). Bangor Dyslexia Test (2nd Ed.). Learning Development Aids.

Mugenda, O. M., \& Mugenda, A. G. (2003). Research methods: Quantitative and Qualitative approaches. Acts Press.Nairobi, Kenya.

Nijakowska, J. (2010). Dyslexia in the Foreign Language Classroom. Bristol: Multilingual matters.

Otach, O. (2008). Abolishing school fees in Africa: Lessons from Ethiopia, Ghana, Kenya, Malawi and Mozambique. Retrieved from http://www.kenpro.org on July 6, 2015.

Policy framework for education and training: Reforming education and training in Kenya. Sessional paper [July] 2012, Ministry of Education, Ministry of Higher Education, Science and Technology, 2012, 133.

Ramus, R., Rosen, S., Dakin, S., Day, B., Castellote, J., White, S., \& Frith, U. (2003). Theories of Developmental Dyslexia: Insights from a Multiple Case Study of Dyslexic Adults. Brain, 126, 841-865.

Rasugu, G. (2010).Nature and prevalence of learning Disabilities among standard three pupils in Starehe division, Nairobi. A master's research thesis: Kenyatta University.

Republic of Kenya, (2005). Sessional Paper No.1 on Policy Framework for Education, Training and Research. Nairobi; (GOK), Government Printer. 
Schulte-Korne, G., Ziegler, A., Deimel, W., Schulacher, J., Plume, E., Bachmann, C., ... Konig, I. R. (2006). Interrelationship and familiarity of dyslexia related quantitative measures. Annals of Human Genetics, 71, $160-175$.

Shanahan, M. A., Pennington, B. F., Yeris, B. E., Scott, A., Boada, R., Willcutt, E. G., \& Olson, R. K. (2006). Processing speed deficits in attention deficit/hyperactivity disorder and reading disability. Journal of Abnormal Child Psychology, 34, 585-602.

Symthe, I., Everatt, J., \& Salter, R. (2004). International book of dyslexia: A guide to practice and resources. Chi Chester, UK: Wiley.

Torgerson, C. J.; Brooks, G., \& Hall, J. (2006). A Systematic Review of the Research Literature on the Use of Phonics in the Teaching of Reading and Spelling. London, UK: DfES.

Vaessen, A., Gerretsen, P., \& Blomert, L. (2009). Naming problems do not reflect a second independent core deficit in dyslexia: Double deficits explored. Journal of Experimental Child Psychology, 103, 202-221.

Vellutino, F. R., Fletcher, J. M., Snowling M. J., \& Scanlon, D. M. (2004). Specific Reading Disability (Dyslexia): What Have We Learnt in the Past Four Decades? Child Psycho, 45, 2-40.

Wanjiku,K.(2015). Effects of Reading Difficulties on Academic Performance of form three students in Public Secondary School,Kiambu County. A Masters Research Thesis. Kenyatta University.

Wong, B. Y. L. (2004). Learning About Learning Disabilities. Canada: Elsevier Academic Press.

World Bank (1990). Primary Education. A World Bank Policy Paper. World Bank

\section{(cc) $\mathrm{EY}$}

This work is licensed under a Creative Commons Attribution 3.0 License. 